\title{
GEOLOGICAL FRAMEWORK OF JURASSIC SEQUENCES, EAST TIBA SUB-BASIN, NORTH WESTERN DESERT, EGYPT
}

\author{
Fahmy M. ${ }^{1}$, Mostafa M. M. ${ }^{1}$, Darwish M. ${ }^{2}$, Saber S. ${ }^{2}$, \\ 1enap Sipetrol, Egypt \\ 2 Cairo University, Faculty of Science, Geology Department.
}

\begin{abstract}
In 2014 and for the first time in East Tiba Sub-Basin exploration history, gas and condensates were tested at commercial rate from the Aalenian Middle Jurassic sandstone reservoir in SH-4well, Shahd/Shahd SE oil fields. This encouraging Jurassic gas discovery gave the initiative to evaluate the Jurassic geological system in the area in order to determine its hydrocarbon potentiality for further exploration and development activities.

The present study revealed that, the area has been subjected to multi-phases tectonic history and had significant effects on the Jurassic sedimentary sequences. Sea level changes induced by tectonics resulted in the deposition of the deltaic complex of the Middle Jurassic Khatatba coal-bearing shales and sandstone reservoir, in addition to the alternating marine sandstones and carbonates of Wadi El Natrun Formation. The hydrocarbon-bearing sandstones are found to be related to the middle interval of Wadi El Natrun Formation that could be correlated stratigraphically with the Middle Jurassic Aalenian sandstone of Gebel Maghara surface outcrop.

A 3D reprocessed PSDM seismic cube has been used, in addition to the well log data, to produce the Middle Jurassic Wadi El Natrun structural map, as it represents a good seismic marker allover the Tiba Sub-Basin.

It is concluded that, the complexity of the deeper Jurassic structural configuration, the quality of the seismic data, the combined stratigraphic and structural prospective traps, the magnitude of the Jurassic fault throws, the terminations of these faults below the younger Cretaceous structural trends and sealing capacity are the critical factors for hydrocarbon generation and entrapment.
\end{abstract}

Keywords: East Tiba Sub-Basin, Middle Jurassic sandstone reservoirs, Wadi El Natrun Formation and Jurassic sedimentary sequences.

\section{INTRODUCTION}

The importance of East Tiba Sub-Basin was highlighted since the oil was commercially discovered for the first time in the Upper Albian Lower Bahariya reservoir sandstones by Enap Sipetrol, after drilling the first three successful exploratory wells (Shahd-1, Gahrd-1 and Rana-1) in 2005 (Enap Sipetrol, 2007). As a result of these oil discoveries, the East Tiba Sub-Basin started to positively show its hydrocarbon resources by drilling more successful exploratory wells, targeting the main Lower Bahariya sandstone reservoirs. The Sipetrol comprehensive exploration activity in East Tiba Sub-Basin led to the formation of the Joint venture PetroShahd Company in 2008, to operate seven discovered development leases namely Shahd, Shahd SE, Diaa, Ghard, Rana, Shebl and Alzahraa development leases (Fig. 1).

In 2014 and for the first time in East Tiba Sub-Basin history, gas and condensates were tested at commercial rate from the Aalenian Middle Jurassic sandstone reservoir in the SH-4well, Shahd/Shahd SE oil fields (Fig.1). This encouraging Jurassic gas discovery gave the initiative to evaluate the Jurassic geological system in the area, in order to determine its hydrocarbon potentiality for further exploration and development activities (Enap Sipetrol, 2016). 
Fahmy, et al.

Fig. 1: Location Map for the studied area (Google Map, 2016)

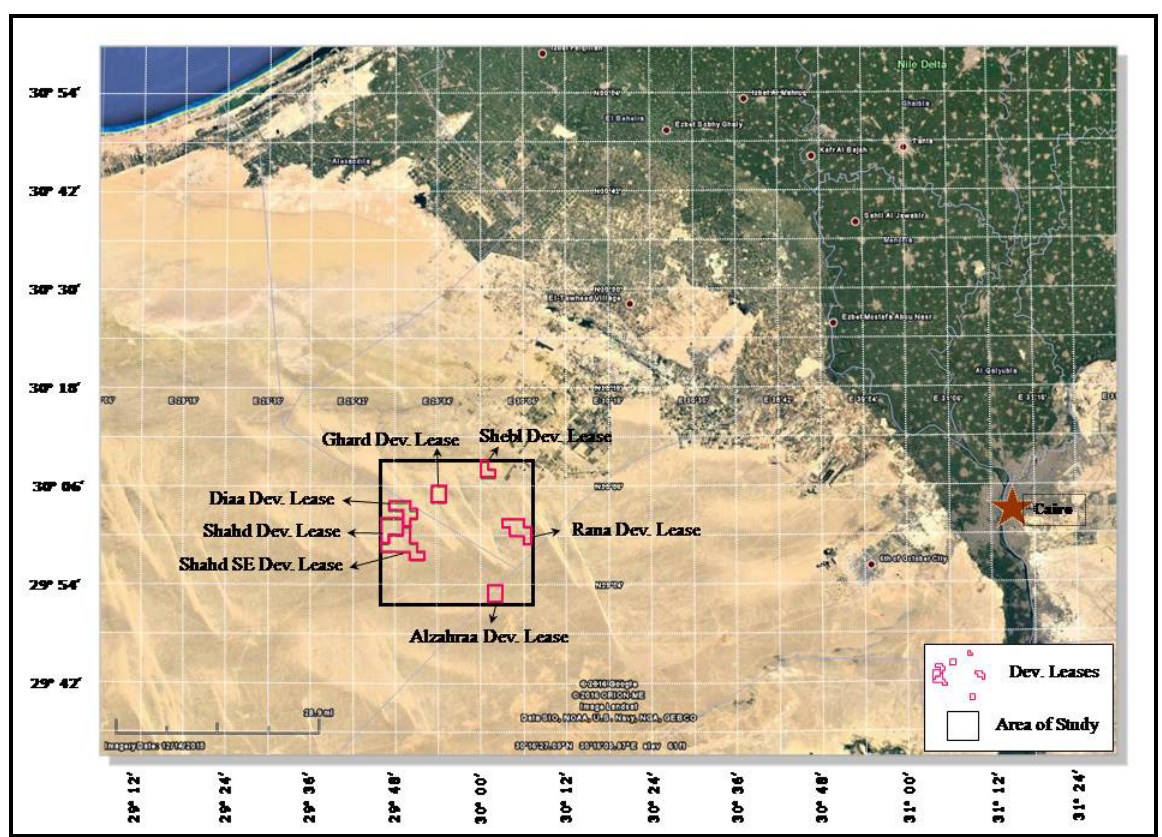

\section{LOCATION OF THE AREA AND THE STRUCTURAL SETTING OF THE NORTH WESTERN DESERT}

The study area is around $126 \mathrm{~km}^{2}$, being located within PetroShahd Concession area, between Latitudes $30^{\circ} 09^{\prime}$ and $29^{\circ} 52^{\prime} \mathrm{N}$ and Longitudes $30^{\circ} 07^{\prime}$ and $29^{\circ} 46^{\prime} \mathrm{E}$ (Fig.1). It is bounded from south by the Kattaniya- Wadi Khadish structural trend and from the north by the Tiba/Zebeida- Sharib Sheiba highs (Fig. 2).

The NE African Mesozoic rift systems have been investigated by many authors, among them Nagati (1986), Meshref (1990), Ayyad and Darwish (1996), Schandelmeier and Reynolds (1997), Guiraud (1998), Badalini et al. (2002) and Darwish and Tewfik (2008). They stated that, "several rift systems were formed, most of which are locatedin the Nile region (e.g. Muglad, Melut, Blue Nile and Atbara in Sudan and Komombo, Nuqra, Sin El Kaddab and Asiut in Egypt”. Other rift basins were developed in the Western Desert of Egypt, such as Matruh, Alamein, Abu Gharadig, Faghour and Shushan (Fig. 2).

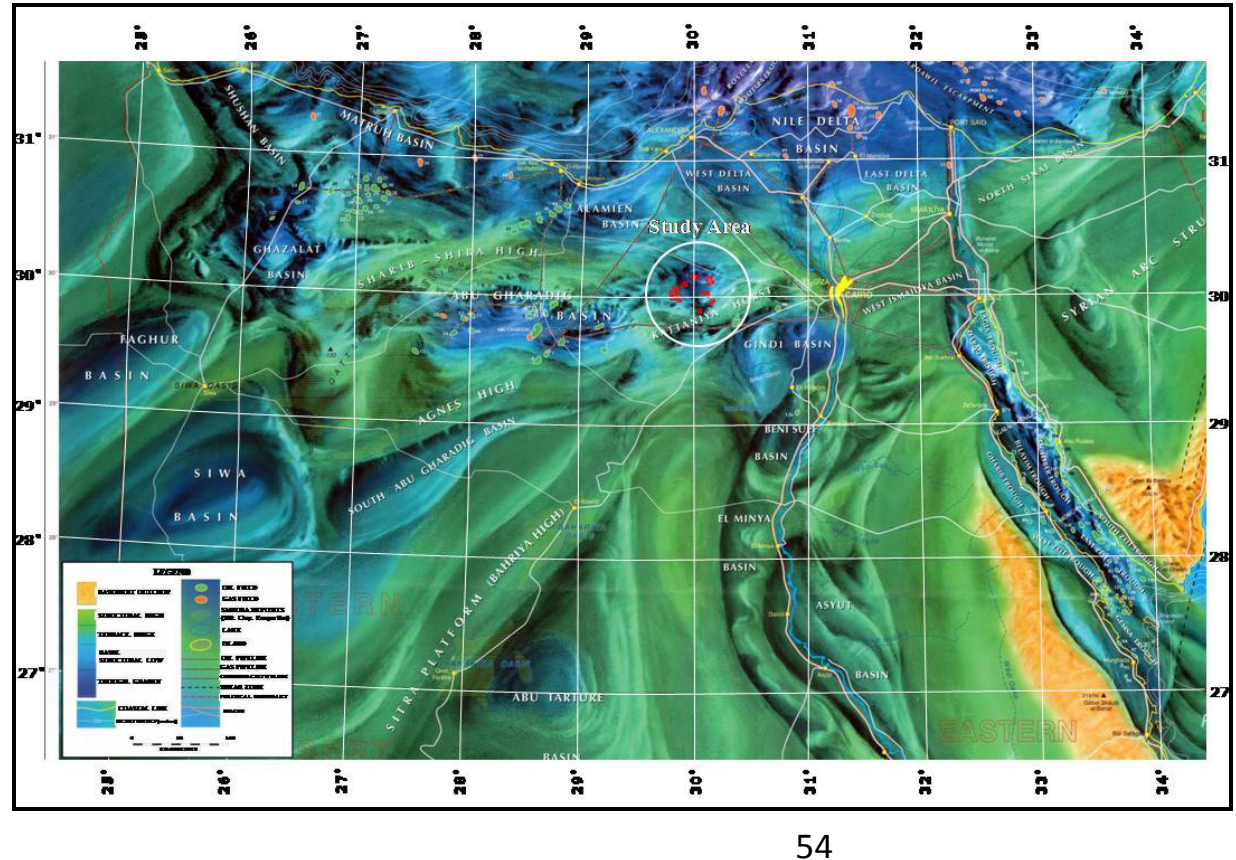

Fig. 2: Regional

Sedimentary Basins, north Western Desert (PGS, 2001) 


\section{Geological framework of Jurassic sequences, East Tiba sub-basin}

Wescott et al., (2011) stated that, "the accurate mapping and understanding of the geometries and distribution of these rifts and associated high blocks is crucial for modelling the hydrocarbon systems and predicting the hydrocarbon occurrences in this region of the Western Desert, as the Jurassic exploration play extends to the east.

Late Cretaceous-Early Tertiary Syrian Arc folds in northern Egypt include both the inverted and noninverted folds. These folds are well exposed in northern Sinai and the northern Eastern Desert, but exist in the subsurface in the northern Western Desert. In northern Sinai, the Maghara, Yelleg, and Halal inversion folds are $45-50 \mathrm{~km}$ long. Similar size inverted folds with opposite vergence exist in the subsurface in the northern Western Desert and include the Kattaniya, Mubarak, Alamein-Razzak and Matruh Basin folds. Smaller non-inverted compressional folds include the Falig and Meneidret El Etheili folds in northern Sinai, as well as the Abu Gharadig mid-basin archs in the subsurface of the northern Western Desert; among others (Fig. 2).

Detailed surface and subsurface structural mapping made use of the excellent exposures, and good 2D and 3D seismic data led to the identification of the fault patterns of the inverted and non-inverted Syrian Arc folds (Moustafa, 2008). Inverted folds have fault patterns that differ from the backlimb to the forelimb. The backlimbs are pervasively dissected by long NW-SE oriented normal faults that were formed by the regional stress field. On the contrary, the forelimbs of inverted folds as well as the two limbs of noninverted folds are affected by the local stress in the folded areas and are dissected by three shorter fault sets; a set of hinge-transverse normal faults and two conjugate sets of hinge-oblique faults, that have oblique-slip. The hinge-oblique faults dominate the steeper limbs of asymmetric non-inverted folds (Moustafa, 2013).

\section{SUBSURFACE SETTING OF EAST TIBA SUB-BASIN}

East Tiba Sub-Basin is located in the northeastern part of the Western Desert. It is considered as a subbasin relative to the major and famous Abu El Gharadig Basin, which is oriented E-W (Figs. 2 and 3). The East Tiba Sub-Basin is a Jurassic-Early Cretaceous half graben bounded on the north by ENE-oriented faults, linked by NE and WNW oriented transfer faults (Figs. 3 and 4). It encompasses three main geological tectonic provinces, the Zebeida High (ridge) in the north, the East Tiba Half Graben in the middle and the Kattaniya Inversion in the southern part. Moreover, the far northwestern corner of the block covers the eastern extension of the Alamein Basin, while the West Delta Basin (Darwish et al., 2000) is located far to the east (Fig. 3).

Fig. 3: East Tiba SubBasin structural setting and including the surrounding tectonic provinces and the nearby fields (Enap Sipetrol G\&G Team, 2004).

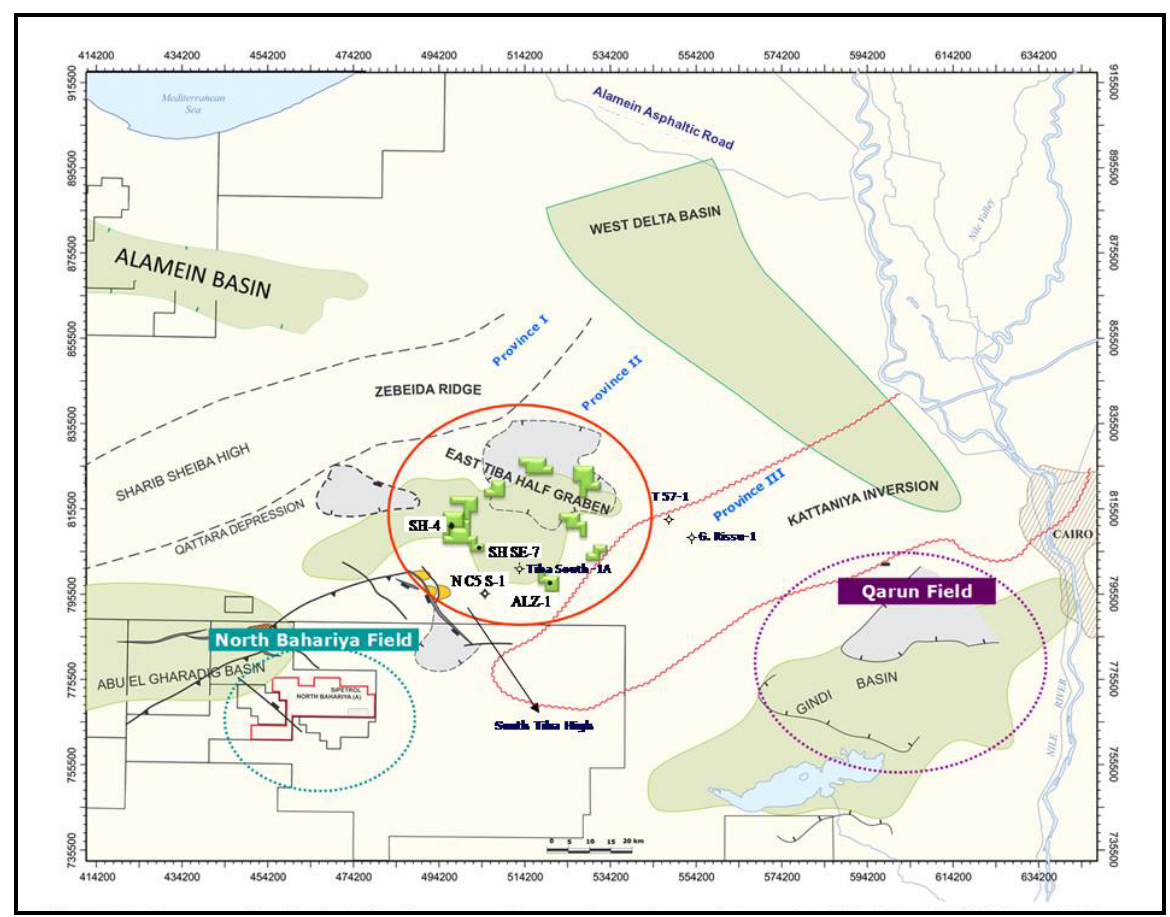


Fahmy, et al.

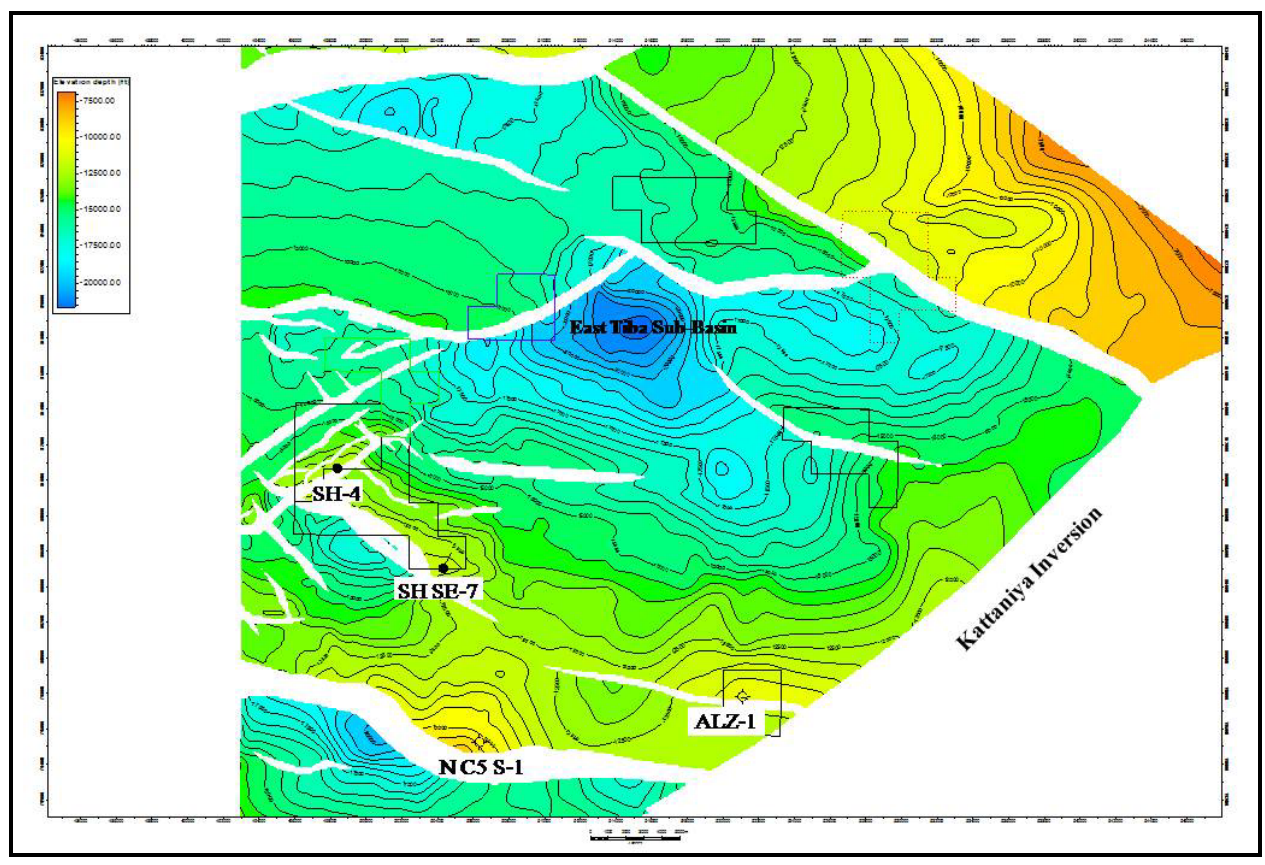

Fig. 4: Wadi El

Natrun Formation structural depth map (Iskander, 2016).

Fig. 4 shows the top of Wadi El Natrun Formation illustrating the configuration of East Tiba Sub-Basin. The structural map revealed the occurrence of more than one three way dip closure bounded from the west by a Cretaceous NW-SE trending normal fault with a maximum throw of $\pm 2700 \mathrm{ft}$. This map shows the presence of two fault trends; a Jurassic NE system and a Cretaceous NW system (Iskander, 2016).

In the East Tiba study area, the detailed stratigraphic setting was examined and determined through the subsurface data obtained from selected wells, as Shahd-1, Ghard-1, Rana-1, SH-4, SH SE-7, ALZ-1, and N C5 S-1 (Fig. 5). The stratigraphic examination and evaluation of these wells are principally focused on the nature of the encountered lithology, formation boundaries, thickness variations, fossil contents, reservoir units and potential hydrocarbon source rocks.

Fig. 5: Wells drilled within and adjacent east Tiba Sub-

Basin and location map (Fahmy and Samy, 2016)

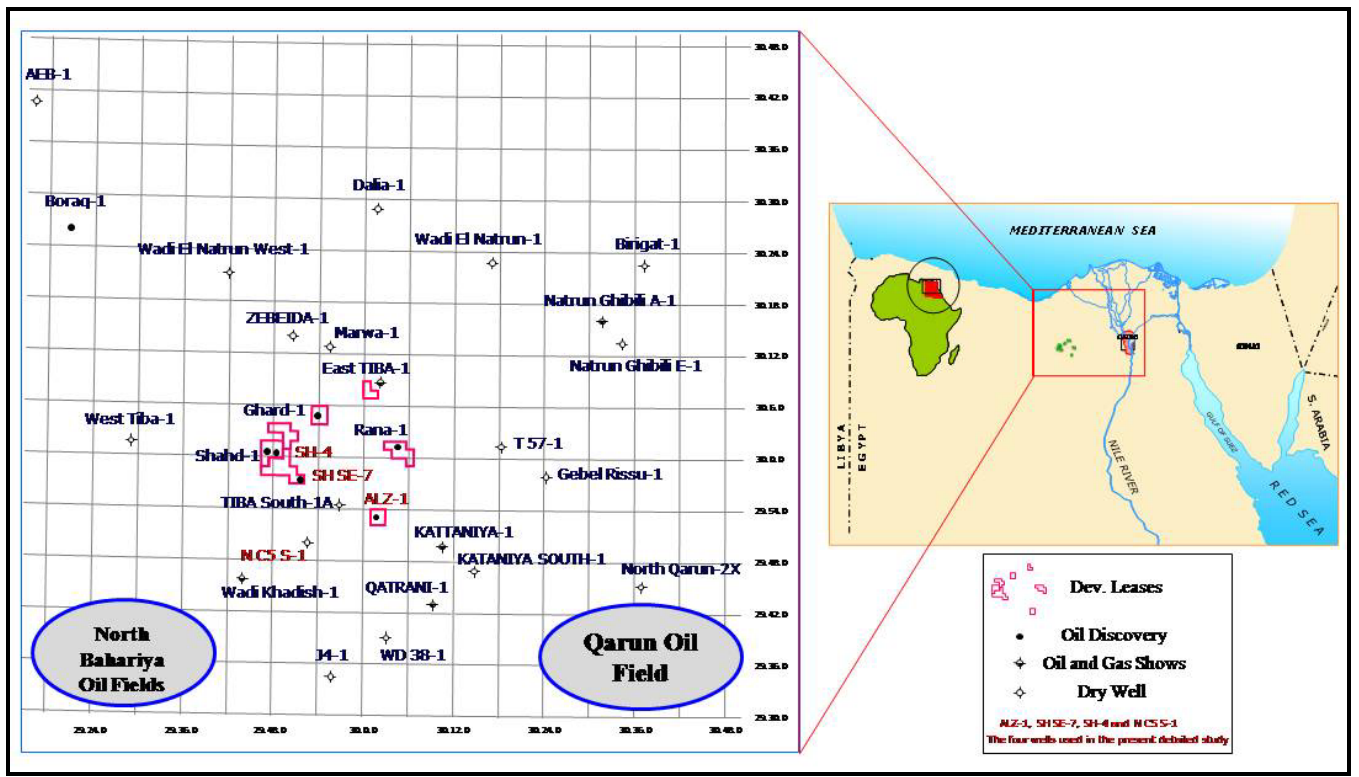

The penetrated stratigraphic sequences are represented by the Phanerozoic sedimentary units, that rest on the Precambrian basement rocks (Fig. 6), which overlain by the oldest well defined sandstone sequences of the Early Jurassic age (continental Ras Qattara Formation). The Jurassic sequences include the carbonate/shale sequences, with thin sandstone interbeds of Wadi El Natrun, Khatatba and Masajid 
formations, from base to top. The Lower to Middle Jurassic Wadi El Natrun Formation could be correlated with the surface outcrops at Gebel Maghara anticline in north Sinai, including Rajabiyah, Shusha and Bir Maghara formations of Al Far (1966). These are unconformably overlain by the Lower Cretaceous sandstone-dominated Alam El Bueib, Alamein, Dahab and Kharita formations of Norton (1967). In the study area, the Aptian Alamein Formation and Early Albian Dahab Formation are most probably absent, due to the partial erosion and/or non-deposition. The main first vast marine transgressive systems on the non-marine clastics of Kharita sandstones are represented by the Bahariya Formation (Late Albian-Early Cenomanian) that is followed upwardly by the carbonate/shale sequences of Abu Roash Formation (Late Cenomanian-Santonian). These were unconformably overlain by the open marine chalk of Khoman Formation (Fig. 6). The Tertiary sequences of clastic/carbonate-dominated facies are represented by the Lower and Middle Eocene Apollonia Formation with the absence of Paleocenesequences, that followed upwardly by the Late Eocene-Oligocene Dabaa Formation. The topmost sequence is the clastic-dominated Moghra Formation of the Early Miocene age (Said, 1962).

As the main task of the present study is to highlight the Jurassic sequences in the Tiba half graben, the following parts will be focused from the top to base on the Masajid, Khatatba, Wadi El Natrun (Bir Maghara, Shusha and Rajabiyah equivalent) and Ras Qattara formations (Fig. 6).

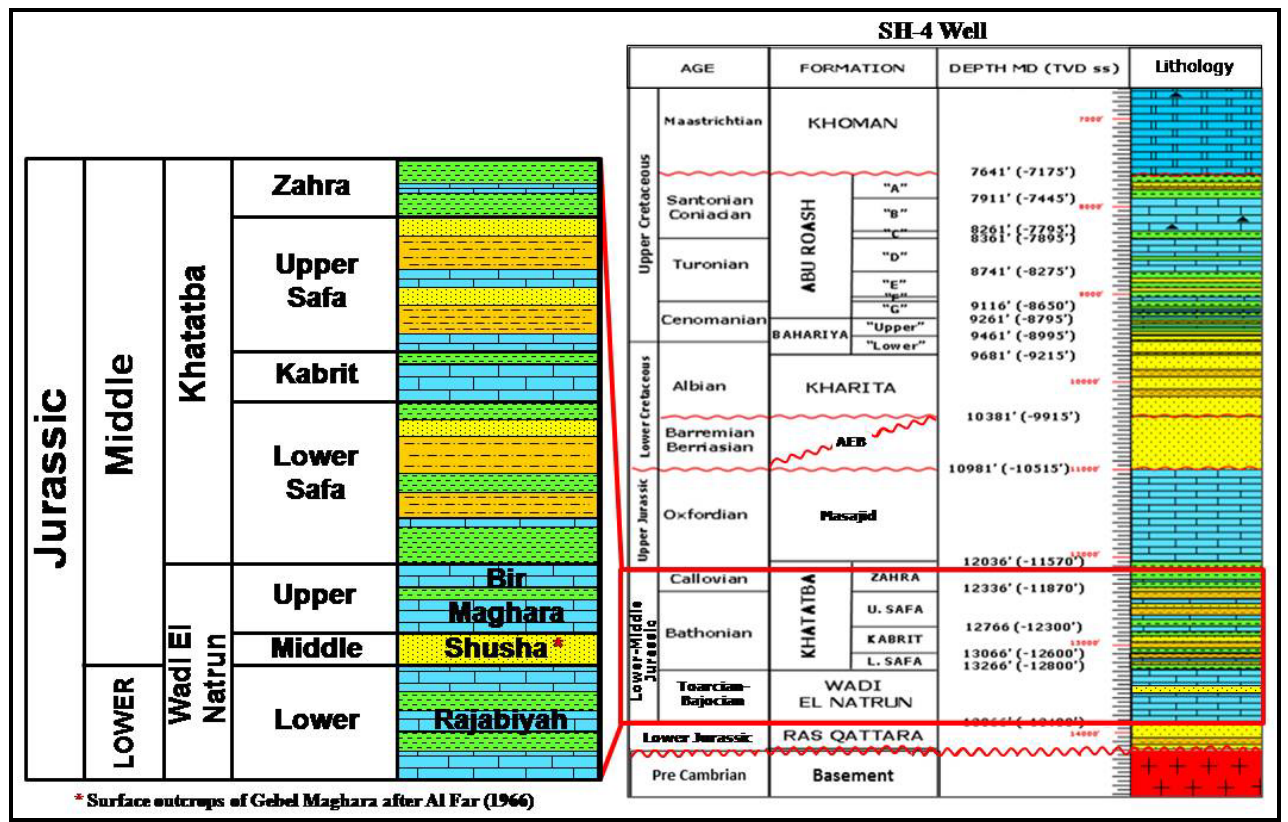

Fig. 6: Generalized litho-stratigraphic column of E.Tiba Sub-Basin, north W. Desert, Middle Jurassic formations are highlighted, Example: $\mathrm{SH}-4$ Well (Sipetrol G \&G Team, Internal Report, 2008)

According to Al Far (1966), the Jurassic sequences of Gebel El Maghara outcrop can be subdivided from base to top into Mashabba Formation (Lower Jurassic), which is described as a cross bedded quartizatic sandstone with plant remains, this is overlain by the sandy and marly hard dense limestone of Rajabiyah Formation (Lower Jurassic), that is followed by the fine to coarse grained sandstone of Shusha Formation (Lower Jurassic). This formation is overlain by the hard massive limestone of Bir Maghara Formation (Middle Jurassic). The sequence of sandstone and flinty limestone, with the main coal seams and plant remains is represented in Gebel Maghara outcrop by Safa Formation (Middle Jurassic); that is overlain by a fossiliferous hard massive limestone with shale intercalations of the Middle to Upper Jurassic Masajid Formation (Fig. 7). Keeley et al. (1991) provided a stratigraphic scheme for the Jurassic sediments of the Western Desert, which can be more or less correlated to the rock succession at G. Maghara (Fig. 7).

\section{GEOLOGICAL FRAMEWORK OF THE JURASSIC SEQUENCES IN EAST TIBA SUB-BASIN}

The subsurface geological framework of the penetrated Jurassic sequences in the East Tiba sub-basin will be discussed from their tectonic domains and stratigraphic aspects, having into consideration the major tectono-stratigraphic Mesozoic Tethyan domain (Guiraud and Bosworth, 1999 and Guiraud, 1999). 
Fahmy, et al.

Fig. 7: Generalized lithostratigraphic column of Jurassic sequences of Gebel El Maghara outcrop, north Saini, Egypt (Al Far, 1966)

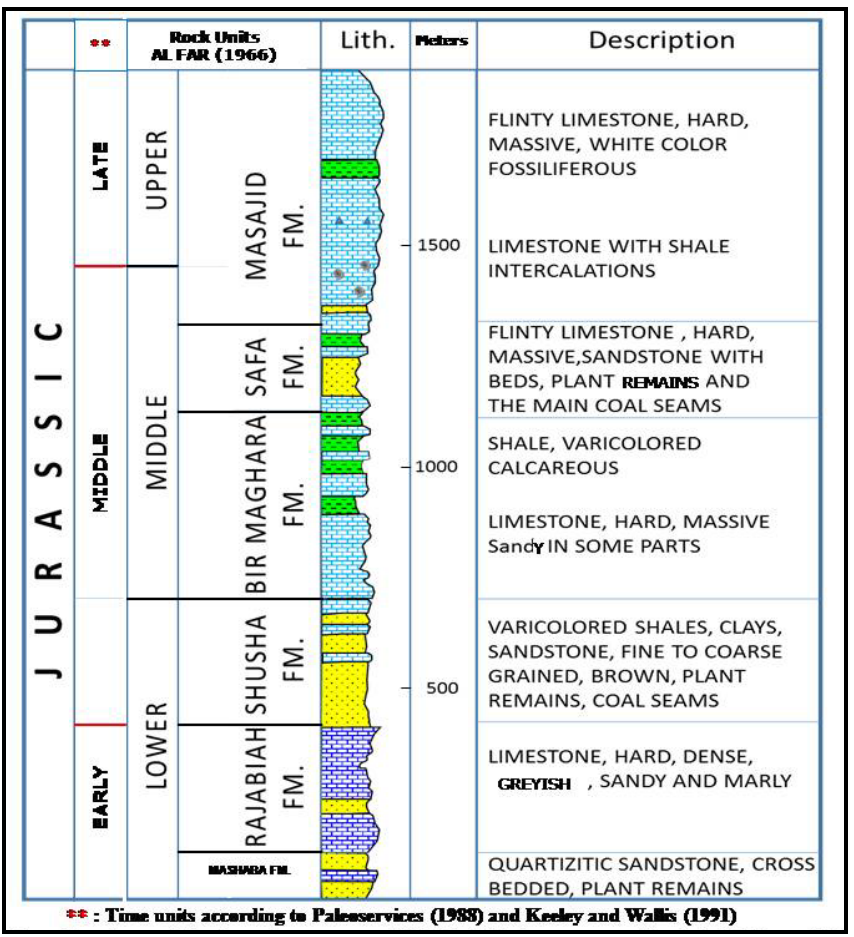

\section{Stratigraphy of the Study Key Wells and Correlation in the East Tiba Sub-Basin}

Four wells have been analyzed in this study to understand the Jurassic sequences in East Tiba Sub-Basin namely SH-4, SH SE-7, ALZ-1 and N C5 S-1 (Fig. 5). However, the stratigraphic correlation is based on the wireline logs patterns that were supported by the well-defined rock-units boundaries and bio-data, having in consideration the main sandstone units, as potential hydrocarbon reservoirs of the Khatatba and Wadi El Natrun rock units.

The Khatatba Formation, stratigraphically, overlies the Wadi El Natrun Formation and underlies the Masajid Formation. Its sandstone reservoirs are represented by thin beds in the study area, whereas the coaly shale and shale facies represent the main hydrocarbon source rocks of the East Tiba sub-basin (Enap Sipetrol, 2007). These shales act also as seals, and thus the Khatatba Formation represents a typical hydrocarbon source-reservoir-seal system (Fig. 8).

Wadi El Natrun Formation, stratigraphically, overlies the Ras Qattara Formation /or the Basement rocks and underlies the Khatatba Formation. It is distinguished into three members as lower, middle and upper. The Middle Jurassic Upper Wadi El Natrun Member built up of middle neritic shallow marine limestone and shales. The lower Jurassic Middle Wadi El Natrun Member is represented by inner to middle neritic shallow marine sandstone, while the Lower Wadi El Natrun Member is built up of inner neritic shallow marine limestone and shale with sandstone intercalation (Figs. 8 and 9).

It is found that, the Middle Jurassic (Late Bathonian) Upper Safa Member is considered the main hydrocarbon reservoir unit in the Khatatba Formation, representing a shallow marine inner to middle neritic zones, based on the bio-data analysis. It consists of intercalated shale, siltstone and sandstone beds, and

coal seams. While the Lower to Middle Bathonian Lower Safa Member is considered as the second reservoir unit in the Khatatba Formation, being deposited in a shallow marine inner to middle neritic zones, based on the bio-data analysis. 
Geological framework of Jurassic sequences, East Tiba sub-basin

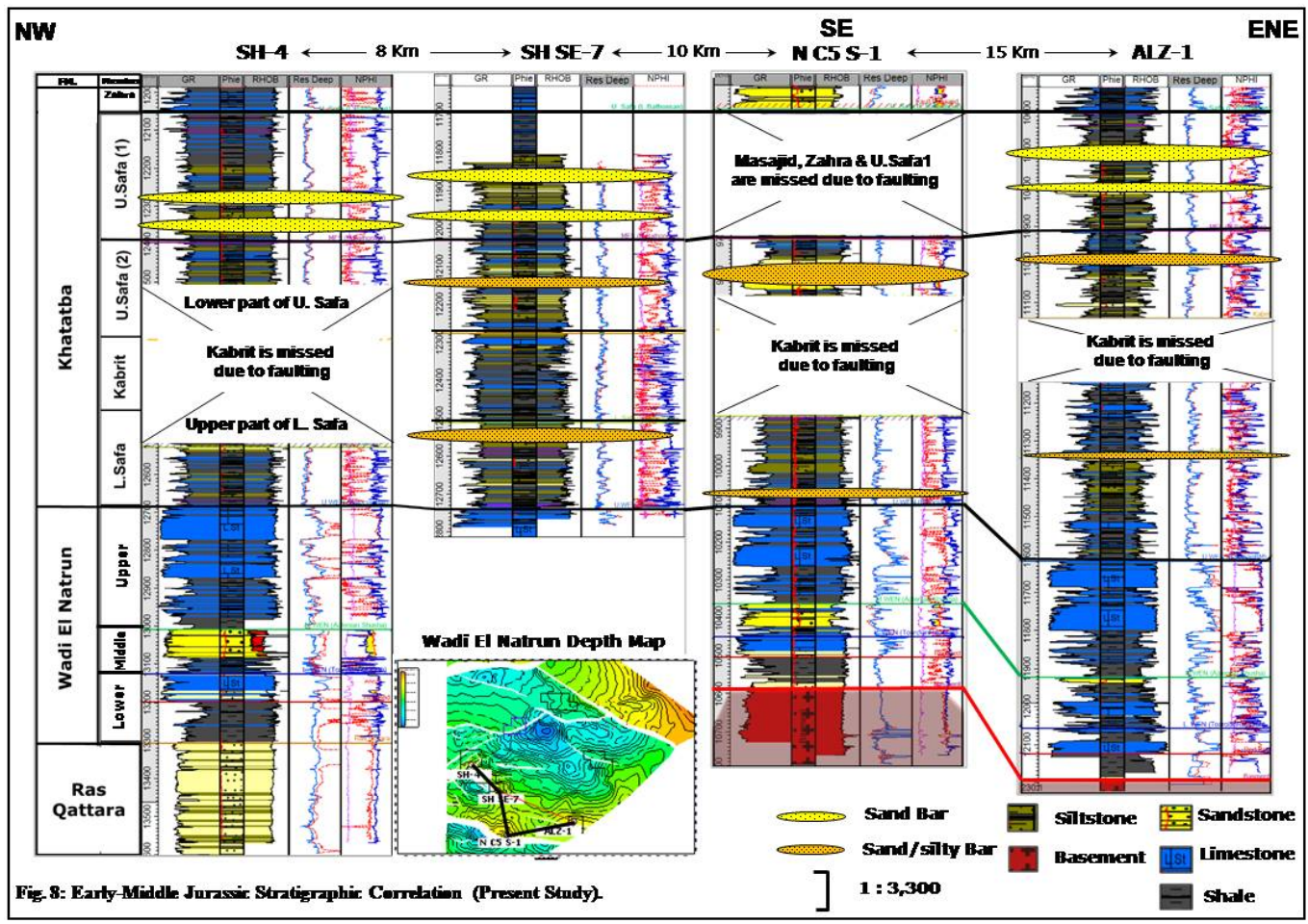

Fig. 8: Early-Middle Jurassic Stratigraphic Correlation (Present Study).

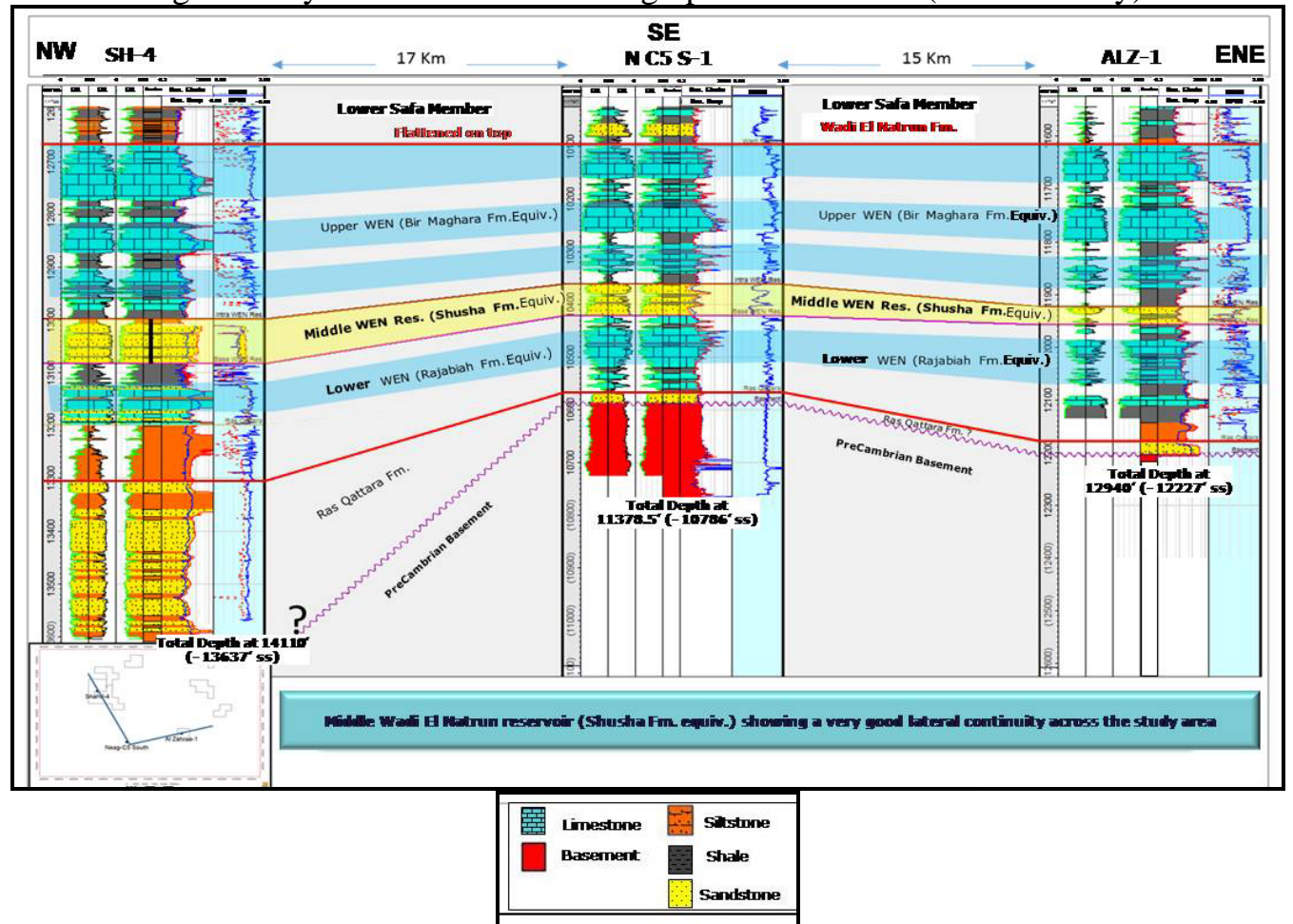

Fig. 9: Wadi El Natrun (WEN) Formation Stratigraphic Correlation, (Present Study).

It consists of intercalated shale, siltstone and sandstone beds, and coal seams. Generally, these sandstones are very limited in distribution (Fig. 8). On the other hand the middle unit of Wadi El Natrun Member is represented in SH-4 well by high net to gross. The correlation shows lateral continuity towards the south at N C5 S-1 and ALZ-1 wells. This unit is sandstone-dominated and being gas prolific in the study area (Fig. 9). 
Fahmy, et al.

Ras Qattara Formation can be subdivided into two members. Upper and Lower being separated from each other by an intra-formational unconformity, as the Lower Jurassic (Sinemurian time) is absent (Georesearch Company, 2015). In addition, the basaltic streaks, that characterize the Lower Ras Qattara Member were dated as Late Triassic/Early Jurassic, based on the K-Ar age dating in Kattaniya-1 well (Fig. 5) (Amoco, 1968).

\section{Biostratigraphic Data Analysis of SH-4 Well:}

Biostratigraphic analysis was carried out on the ditch samples over the interval of $11210 \mathrm{ft}-14110 \mathrm{ft}$ (T.D.) from SH-4 Well (Figs.10 and 11). The studied section ranges from Early Jurassic (Late Hettangian) to Late Jurassic (Late Oxfordian) in age. The first analysed sample at depth $11210 \mathrm{ft}$. is the marine carbonate and shale of Masajid Formation.

The massive carbonate of Masajid Formation of the Middle/Early Oxfordian age encountered at depth $11340 \mathrm{ft}$. which conformably overlies the lower limestone unit of Masajid Formation of the Late to Middle Callovian age at depth interval of $11750 \mathrm{ft}-12010 \mathrm{ft}$. The relatively shales and limestone sequences of the Khatatba Formation (Zahra Member of the Early Callovian age) are encountered at depth interval of 12010

$\mathrm{ft}-12520 \mathrm{ft}$. conformably overlies the Middle to Late Bathonian Khatatba Formation (Upper Safa Member). The Upper Safa carbonaceous shales and sandstones (interval 12520-12950 ft.) overlies the Lower Safa carbonaceous shale and sandstones of the Early to Middle Bathonian age at depth interval $12950 \mathrm{ft}$.- $13160 \mathrm{ft}$., which conformably overlies the carbonates of the upper unit of Wadi El Natrun Formation (Bir El Maghara Formation equivalent).

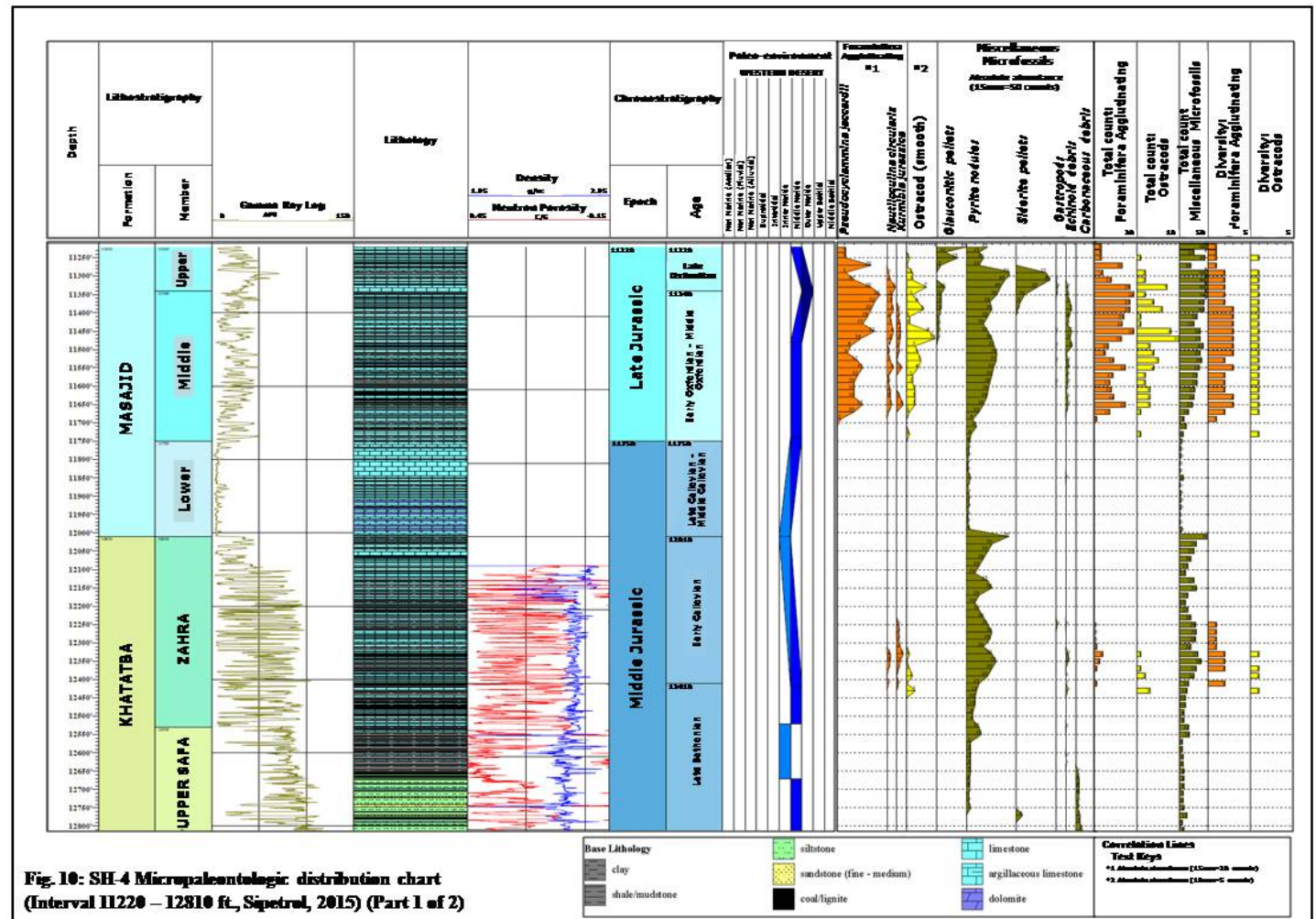

Fig. 10: SH-4 Well micropaleontology distribution chart, (Georesearch, 2015) (part 1 of 2).

The shale and limestone of Bir Maghara Formation of the Early to Late Bajocian are encountered at the depth interval of $13160 \mathrm{ft} .-13480 \mathrm{ft}$. and conformably overlie the sandstones of Aalenian age of Shusha Formation at the depth interval $13480 \mathrm{ft}-13600 \mathrm{ft}$. The Shusha Formation of the Middle Jurassic (Aalenian age) conformably overlies the limestones and shale of the lower unit of Wadi El Natrun Formation (Rajabiyah Formation equivalent) of Early Jurassic (Toarcian age) at the depth interval of $13600 \mathrm{ft}$-13740 ft. The Rajabiyah Formation conformably overlies the sandstones of the Upper Ras Qattara Member (Mashabba Formation equivalent) of the Early Jurassic (Late 
Geological framework of Jurassic sequences, East Tiba sub-basin

Pliensbachian) at the depth interval of 13740 t.-14040 ft., which unconfomably overlies the Lower Ras Qattara Member of the Early Jurassic (Late Hettangian) at the depth interval of $14040 \mathrm{ft}$-14110 ft. total depth.

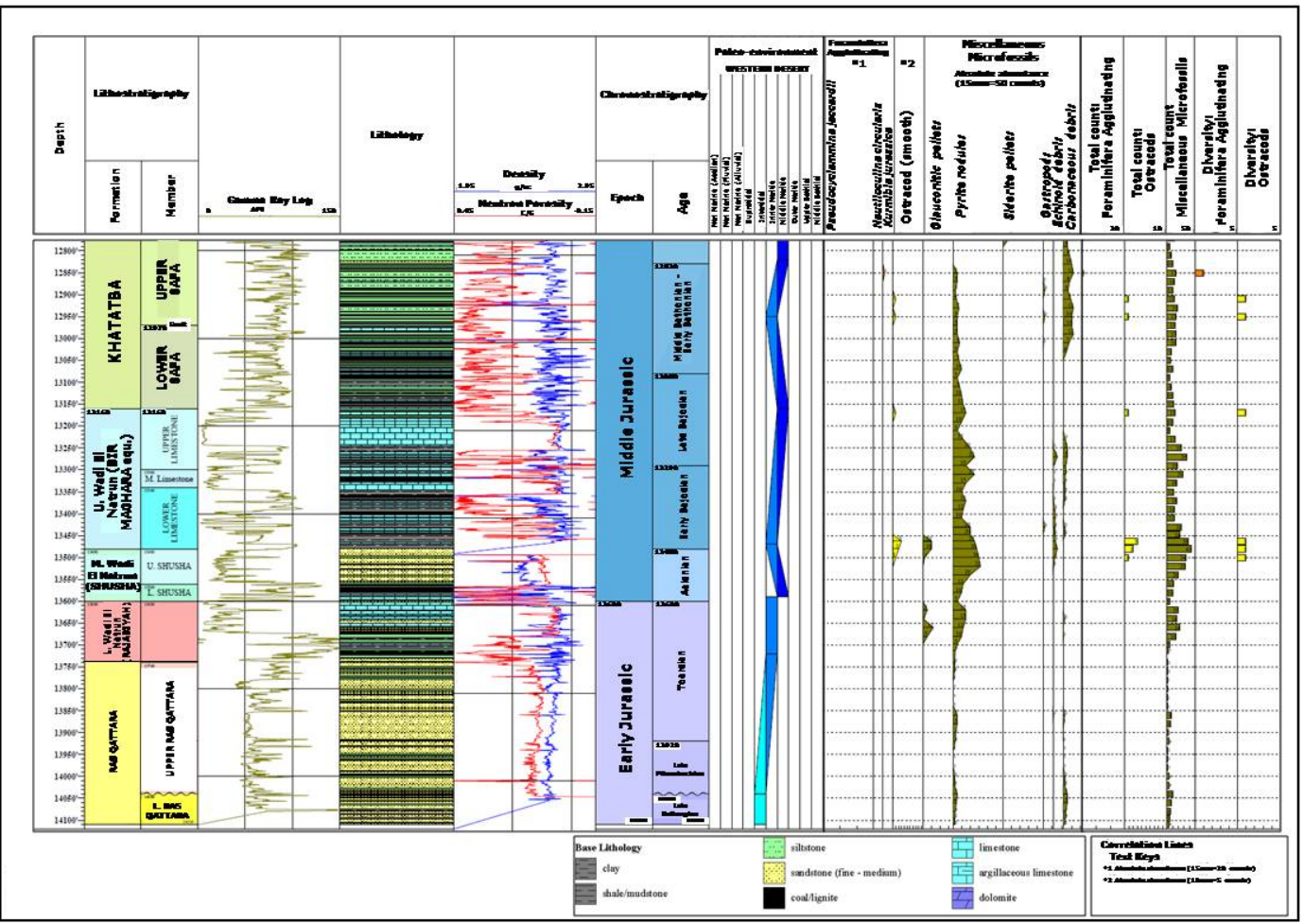

Fig. 11: SH-4 Well micropaleontology distribution chart, (Georesearch, 2015) (part 2 of 2).

The paleo-environments of the different units of the Jurassic section can be identified, based on the fossil assemblages recorded from the micropaleontological analysis, as shown in table no.1 and figs.10 and 11.

\section{Jurassic Stratigraphic Panels in the Context of East Tiba Sub-Basin:}

In addition to the four wells in the East Tiba Sub-Basin area (SH-4, SH SE-7, AlZ-1 and N C5 S-1 wells), nineteen revised wells have penetrated the Jurassic succession in the nearby areas, especially in the Gebel Rissu Basin; where complete Jurassic sequences were drilled (Fig. 5). Table no.2 is summarizing all the available Jurassic well data in the surrounding areas that have been used in the present study.

The time stratigraphic sequences, sediment supply, basin fill, paleo-topography and reservoir sandstone distributions were determined through the litho and bio-stratigraphic interpretation, in addition to the electric-logs for the constructed three regional correlation panels (Figs.12-14) aiming to delineate the basinal and ridge features during the deposition of Ras Qattara Formation upwardly to Wadi El Natrun and Khatatba formations. The correlation lines were selected to extend from the western Sheiba high, passing through the East Tiba Sub-Basin to the eastern Gebel Rissu Jurassic Basin (Figs.15 and 16).

The regional correlation (Fig.14) shows that, the Lower Ras Qattara Member consists of varicolored, mainly reddish-brown, section of sandstone and siltstone, with several basaltic intrusions dated Late Triassic-Early Jurassic in Kattaniya-1 well core samples, using the K-Ar. dating (Kattaniya-1 well final well report, 1968). This varicolored sandstone section is most probably representing the initial Jurassic non marine rift sediments (500 ft.) and unconfomably overlies the Precambrian Basement rocks in the J4-1 Well (Fig.14). Such rifting occurred at the Triassic- Early Jurassic accompanied with the uplifting, that produced the continental facies of Ras Qattara Formation. 
Fahmy, et al.

Table 1: SH-4 Well Jurassic Section Paleo-environments

\begin{tabular}{|c|c|c|c|c|c|c|}
\hline Interval (Feet) & Environment & Formation & Member & Age & & \\
\hline $11750-12010$ & Middle neritic to inner neritic & Masajid & Lower Limestone & Late-Middle Callovian & \multirow{9}{*}{$\frac{\vartheta}{\tilde{z}}$} & \\
\hline $12010-12410$ & Inner neritic to Middle neritic & \multirow{6}{*}{ 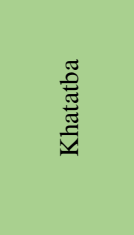 } & Zahra & Early Callovian & & \\
\hline $12410-12520$ & Middle neritic & & & & & \\
\hline $12520-12670$ & Inner neritic & & & & & \\
\hline $12670-12830$ & Middle neritic & & Upper Safa & Middle to Late Bathonian & & \\
\hline $12830-12950$ & Middle neritic to inner neritic & & & & & \\
\hline $12950-13160$ & Inner neritic to Middle neritic & & Lower Safa & Early to Middle Bathonian & & \\
\hline $13160-13480$ & Middle neritic & \multirow{3}{*}{ 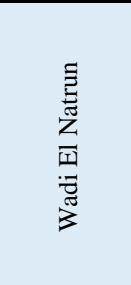 } & $\begin{array}{c}\text { Upper Unit } \\
\text { (Bir El Maghara Fm. } \\
\text { equivalent) }\end{array}$ & Early to Late Bajocian & & $\begin{array}{l}-1 \\
5 \\
n \\
0 \\
7\end{array}$ \\
\hline $13480-13600$ & Inner neritic to Middle neritic & & $\begin{array}{l}\text { Middle Unit } \\
\text { (Shusha Fm. } \\
\text { equivalent) }\end{array}$ & Aalenian & & ב \\
\hline $13600-13740$ & Inner neritic & & $\begin{array}{l}\text { Lower Unit } \\
\text { (Rajabiyah Fm. } \\
\text { equivalent) }\end{array}$ & Toarcian & \\
\hline $13740-14040$ & Inner neritic to Intertidal & \multirow{2}{*}{ 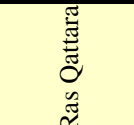 } & $\begin{array}{c}\text { Upper Unit } \\
\text { (Mashabbah Fm. } \\
\text { equivalent) }\end{array}$ & Late Pliensbachian & & \\
\hline $14040-14110$ & Intertidal & & Lower Unit & Late Hettangian & & \\
\hline
\end{tabular}

Table 2: The available Jurassic wells data in the surrounding areas that were used in the present study of East Tiba Sub-Basin. Data source is E.G.P.C. (Egyptian General Petroleum Corporation) final well reports

\begin{tabular}{|c|c|c|c|c|c|}
\hline$\#$ & Well Name & $\begin{array}{c}\text { Khatatba } \\
\text { Thicknesses (FT) }\end{array}$ & $\begin{array}{l}\text { Wadi El Natrun } \\
\text { Thicknesses (FT) }\end{array}$ & T.D. (MD FT) & Formation T.D. \\
\hline 1 & $\mathrm{SH}-4$ & 1350 & 600 & 14110 & RAS QATTARA \\
\hline 2 & SH SE-7 & 1399 & ---- & 14530 & UPPER WADI EL NATRUN \\
\hline 3 & ALZ-1 & 1350 & 578 & 12940 & BASEMENT \\
\hline 4 & N C5 S-1 & F/C, 429 & 480 & 11378 & BASEMENT \\
\hline 5 & Dalia-1 & 1315 & 613 & 14563 & WADI EL NATRUN \\
\hline 6 & Birigat-1 & 1600 & 802 & 11381 & WADI EL NATRUN \\
\hline 7 & Wadi El Natrun-1 & 1740 & 738 & 13348 & BASEMENT \\
\hline 8 & Natrun Ghibili A-1 & 2355 & $\begin{array}{ll}-- \\
\end{array}$ & 12944 & LOWER SAFA \\
\hline 9 & Natrun Ghibili E-1 & 2650 & 930 & 14764 & BOTTOM WADI EL NATRUN \\
\hline 10 & T 57-1 & 3550 & 2100 & 11571 & WADI EL NATRUN \\
\hline 11 & Gebel Rissu-1 & 3150 & 1924 & 11598 & RAS QATTARA \\
\hline 12 & Wadi Khadish-1 & 1233 & ---- & 6495 & UPPER WADI EL NATRUN \\
\hline 13 & Kattaniya South-1 & 3300 & 1485 & 12728 & RAS QATTARA \\
\hline 14 & Kattaniya-1 & 2300 & 1450 & 13295 & INTRUSION \\
\hline 15 & Qatrani-1 & 1766 & --- & 7500 & UPPER WADI EL NATRUN \\
\hline 16 & North Qarun-2X & 695 & 868 & ---- & UPPER WADI EL NATRUN \\
\hline 17 & WD 38-1 & 1120 & $\begin{array}{ll}--- \\
\end{array}$ & 9715 & RAS QATTARA \\
\hline 18 & $\mathrm{~J} 4-1$ & 814 & 1102 & 12800 & BASEMENT \\
\hline 19 & West Tiba -1 & 1418 & ---- & 12110 & BAHRIEN \\
\hline 20 & Zebida-1 & 1353 & 597 & 12566 & WADI EL NATRUN \\
\hline 21 & Wadi El Natrun West-1 & 900 & $\begin{array}{ll}--- \\
\end{array}$ & 11628 & BOTTON KHATATAB \\
\hline 22 & Boraq-1 & 1550 & 0 & 14715 & BAHREIN \\
\hline 23 & AEB-1 & 2400 & --- & 15500 & LOWER SAFA \\
\hline
\end{tabular}

For well location, refer to the location map (Fig.5) and the isochore maps (Figs.15 and 16).

\section{Middle Jurassic Isochore Maps}

The thickness distributions of the main stratigraphic units in the study area are represented by isochore maps (Figs.15 and 16) for Wadi El Natrun and Khatatba formations.

\section{Wadi EI Natrun Isochore Map}

The NE-SW orientation of the Gebel Rissu Basin, where, more than 1800' thick section of Wadi El Natrun Formation was deposited (Fig. 15). The paleo-shore line of Wadi El Natrun Formation is located most probably west of Tiba W-1 and WQ 56/4-1 wells, where the Sheiba-Misawag paleo-topographic 


\section{Geological framework of Jurassic sequences, East Tiba sub-basin}

highs occur. These were extended south of the basin that was occupied by the Precambrian Basement rocks. These paleo-highs were capped by fluvial Nubian type sandstone facies (time equivalent of Wadi El Natrun Formation). The non-availability of the Wadi El Natrun thickness data at the western part, makes it difficult to follow the westward high.

Fig. 12: A-A’ Jurassic Stratigraphic Correlation, (Present Study)
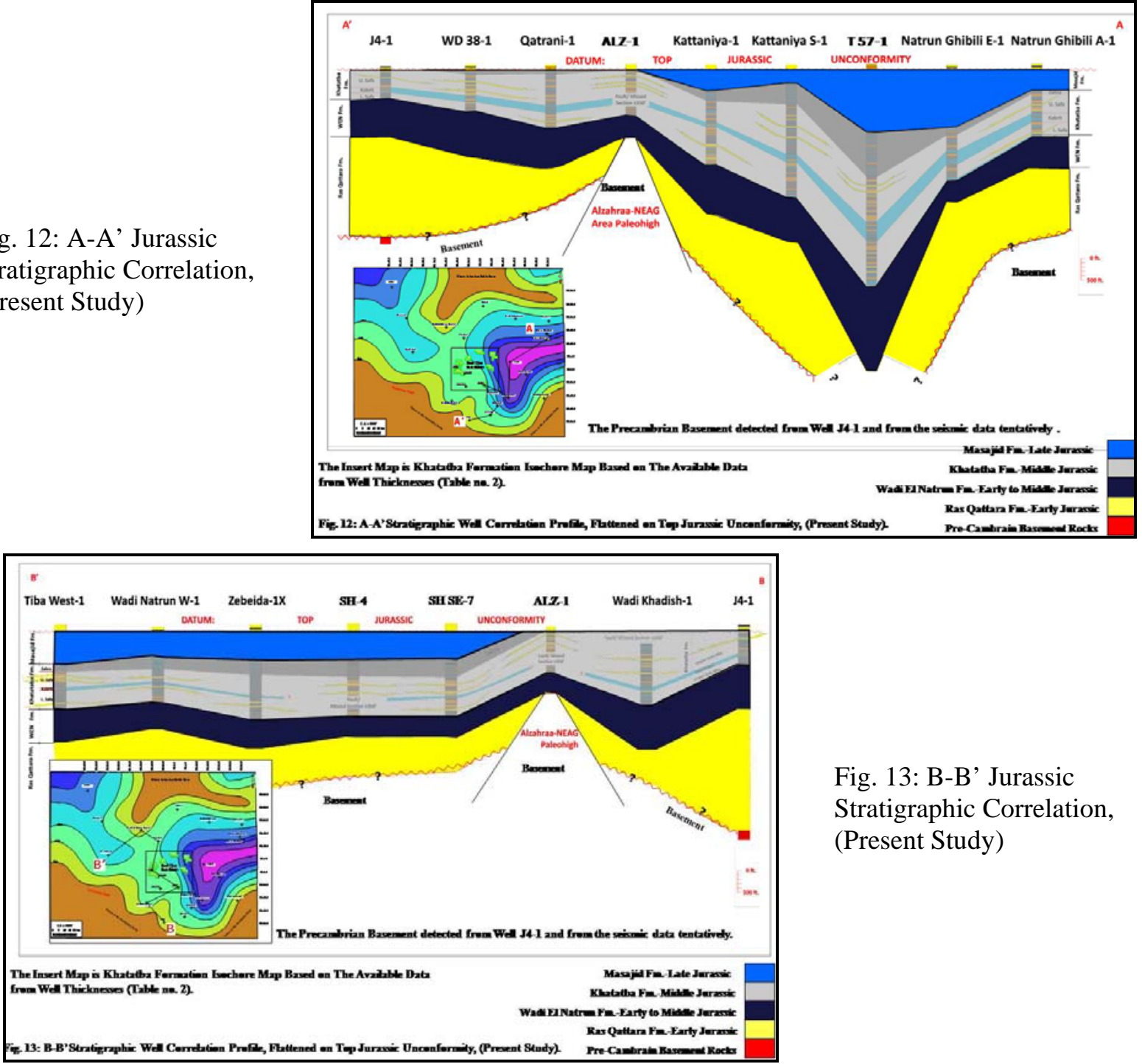

Fig. 13: B-B' Jurassic Stratigraphic Correlation, (Present Study)

\section{Khatatba Isochore Map}

More than $3000 \mathrm{ft}$. thickness of the Bathonian Khatatba sediments had been penetrated by T57-1 and Gebel Rissu-1 wells within the depocentre of Gebel Rissu Basin (Fig.16). This basin, of NE-SW trend, seems to be active around the area of T57-1 and Gebel Rissu -1 wells. This re-activated basin encompasses the local trough areas that previously occupied by the Sheiba and Misawag highs, where about $1500 \mathrm{ft}$. of the Khatatba Formation was deposited (Fig.16).

\section{Jurassic Sequences Cyclicity and Depositional Regimes}

The Jurassic sedimentary record in the East Tiba Sub-Basin is essentially a result of interaction of tectonics, eustatic sea level changes and climate. The tectonics and eustasy are controlling the size and shape of the basin, volume of accumulated sediments, while the climate is controlling the sediment type and supply. Therefore, the vertical and lateral basin sedimentary fill and depositional regimes through time are strongly related to the periodic changes of the above mentioned factors (Enap Sipetrol, 2016). 
Fahmy, et al.

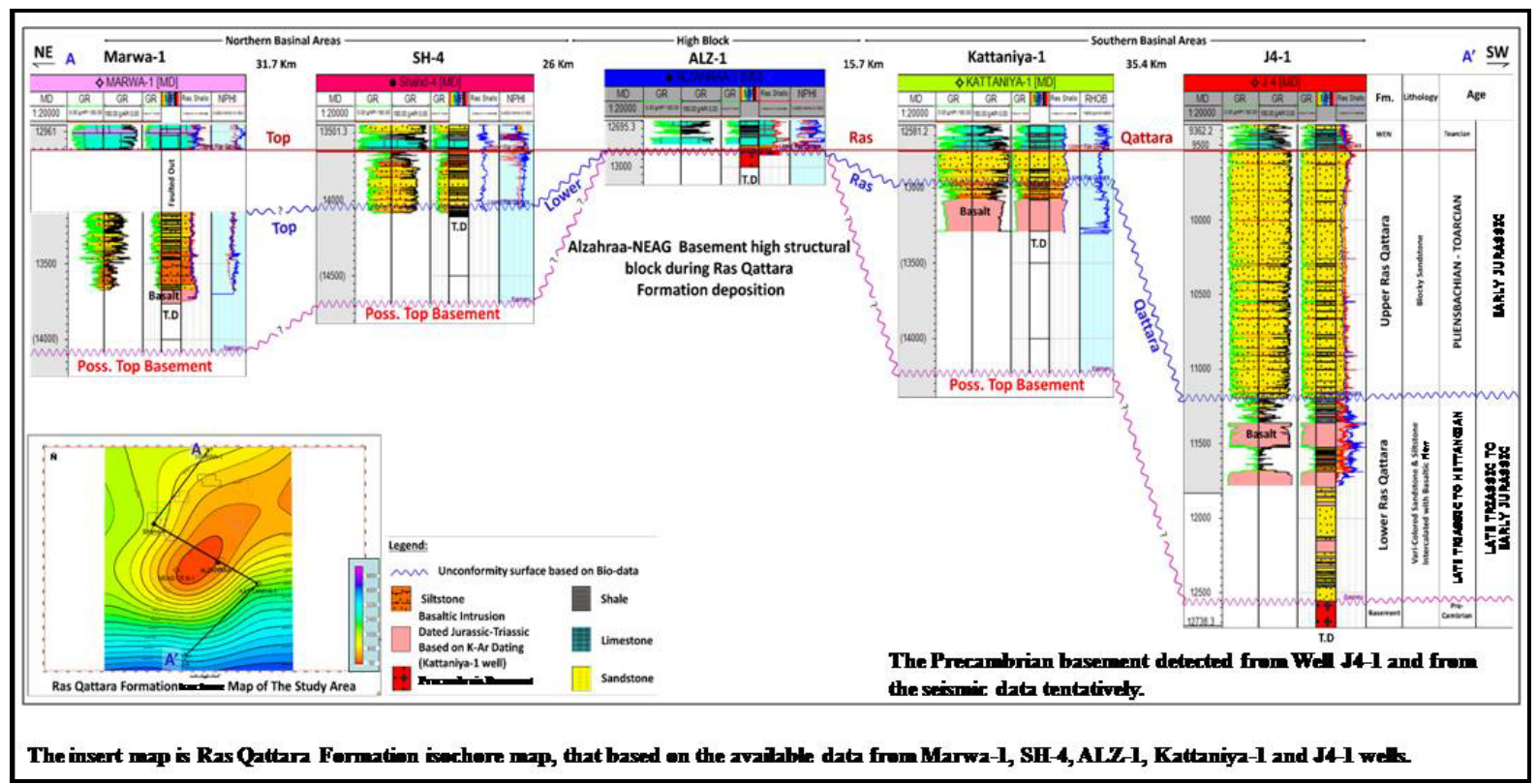

Fig. 14: Lower Jurassic Ras Qattara Stratigraphic Correlation, Profile along Wells Marwa-1, SH-4, ALZ-1, Kattaniya-1 and J4-1 (Present Study).

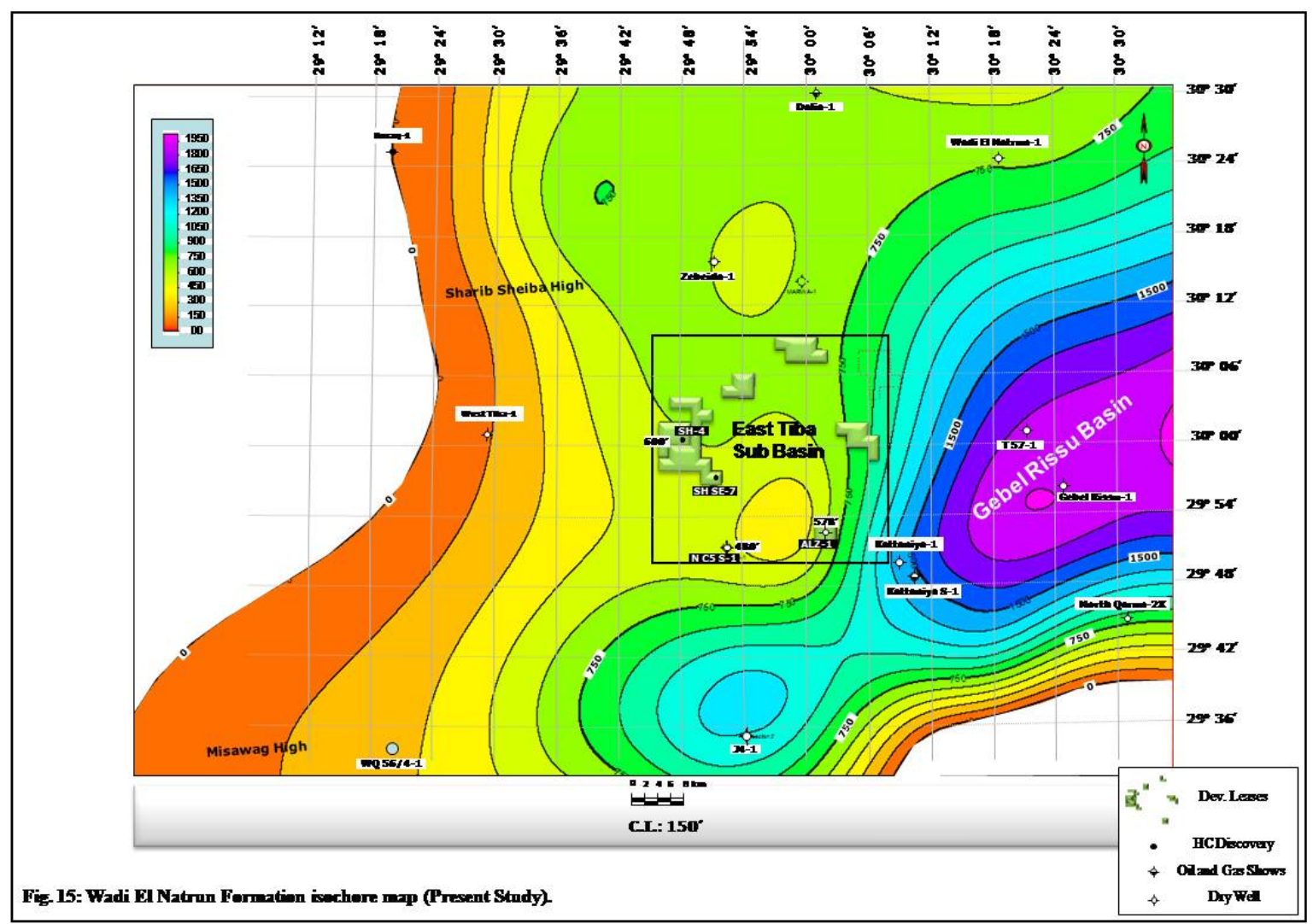

Fig. 15: Wadi El Natrun Formation Gross Isopach Map (Present Study).

In order to understand the Jurassic depositional regimes, the cyclo-stratigraphic concept is applied to the Jurassic successions drilled by the two Jurassic wells SH-4 and SH SE-7 in Shahd/Shahd SE oil fields, in addition to ALZ-1 well (Fig.5). The surrounding wells, drilled in Gebel Rissu Basin were also revised (Table no.2). In the present study three Jurassic mega sequences could be recognized as lower clasticdominated, middle mixed clastic/carbonate and an upper carbonate-dominated (Figs. 6 and 7): 
Geological framework of Jurassic sequences, East Tiba sub-basin

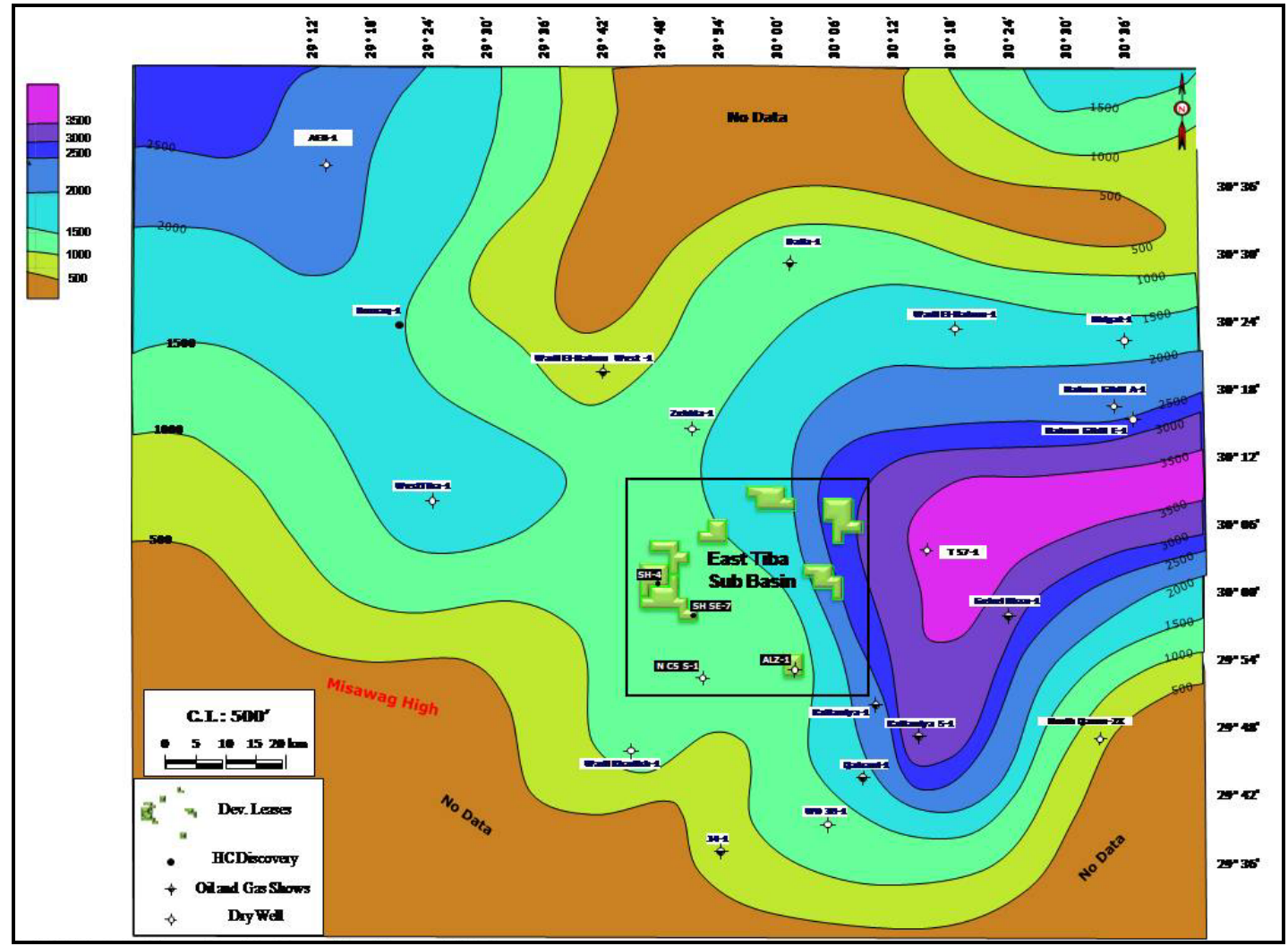

Fig. 16: Khatatba Formation Gross Isopach Map (Present Study)

The following main interpreted results could be summarized from these regional correlation panels as follows:

1. Gebel Rissu-1, Natrun Gibili-1, J4-1 and T 57-1 wells areas were the depocentres of the basin, since the Early Jurassic time. Thick sediments of Ras Qattara, Wadi El Natrun and Khatatba formations were accumulated in a NE-SW oriented basin, named as "Gebel Rissu Basin", during the Early to Middle Jurassic times.

2. J4-1 well is located at the SW axial part of Gebel Rissu Basin, is bottomed in the Basement rocks at depth 12,800 ft. MD. The well has penetrated a very thick section of Ras Qattara sandstones (3024 ft. thick.) above the Precambrian basement rocks.

3. The Lower Ras Qattara sandstones were interrupted by several basic volcanics. These basaltic rocks were dated in Kattaniya-1 well as Late Triassic-Early Jurassic, by using the K-Ar dating; (Amoco, 1968). This is happened basically through the Alzahraa-NEAG paleohigh.

4. Ras Qattara sandstones disappeared laterally, due to the erosion and/or non-deposition from Gebel Rissu basin westwards to Sheiba and Misawag highs. This is reflects to the maritime affinity of G. Rissu Basin.

5. A clear thinning of Wadi El Natrun Formation from Gebel Rissu Basin towards Sheiba-Misawag highs (Fig.15). In addition, the marine carbonate/shale parts of the lower Wadi El Natrun Member disappeared laterally westwards, due to the non-deposition. This is due to the positive tectonics of Sheiba-Misawag and Alzahraa-NEAG paleohighs.

6. During the Bathonian time, the Sheiba-Misawag highs were converted into basinal areas, where a thick Khatatba Formation was deposited over the continental barren Nubian type sandstone facies of the Early/Middle Jurassic. This is occurred typically at T 57-1 well.

7. The Masajid Formation shows a thicker section in the basin depocentral areas and thinning towards the margins of the basin. It disappeared completely at Alzahraa/Wadi Khadish paleo-high and the southern flank of the basin (Figs.12 and 13). Such Masajid thickening is clear at T 57-1 and Natrun Ghibibi-1 wells. 
Fahmy, et al.

The correlation with the exposed Gebel Maghara Jurassic surface section in North Sinai revealed that, Mashabba Formation is the stratigraphic equivalent to the Upper Ras Qattara sandstone Member. According to Al-far (1966), the Mashabba Formation is the oldest exposed unit at Gebel Maghara area and consists of a sandstone section, with some plant remains. The sandstone is highly cemented by calcite and sedritic cement.

The Upper Ras Qattara Member was penetrated by SH-4well, consisting of $350 \mathrm{ft}$. of tight sandstone section, dated Early Jurassic (Pliensbachian) and rests unconformably over the drilled $50 \mathrm{ft}$. of the Lower Ras Qattara Member (the well was bottomed in the Lower Ras Qattara Member).

\section{Lower Clastics Mega-Sequence}

This sequence is represented by Ras Qattara Formation and Lower and Middle members of Wadi El Natrun Formation (sandstones/shales and thin carbonates). This facies is representing fluvial to shallow marine depositional regimes during the initial and early phase of Jurassic rifting (Enap Sipetrol, 2016).

In the well SH-4 as in Gebel Maghara exposed Jurassic section, the subsurface Ras Qattara Formation is directly overlain by the shallow marine section composed of limestone and shale. This carbonate section (Figs.6 and 7) is referred to at Gebel Maghara area as Rajabiyah Formation (Al Far, 1966). The fossil content of this section in SH-4 well assigned it to the Early Jurassic age (Toarcian). Upward in the sequence in both SH-4 well and Gebel El Maghara outcrop, the Rajabiyah Formation is overlain directly by the Shusha Formation. The fossil content of the Middle Wadi El Natrun member (Shusha Formation equiv.) in SH-4 well assigned it to the Aalenian Middle Jurassic age (SH-4 bio-stratigraphic report, Georesearch Company, 2015). In the present study the Rajabiyah and Shusha formations of Al Far (1966) are found to be correlated to the lower and the middle parts of the subsurface Wadi El Natrun Formation of Norton (1967). The later is well known in the Jurassic stratigraphy of the Western Desert.

At Gebel El Maghara outcrop; the Shusha Formation consists mainly of sandstone section with plant remains and some coal seams representing the repetition of the deltaic complex depositional regimes that prevailed during the deposition of the Mashabba Formation (Al Far, 1966).

\section{Middle Mixed Silisiclastics/Carbonate Mega-Sequence}

In SH-4 well this sequence is lithologically represented by the upper carbonate / shale unit of Wadi El Natrun and Khatatba formations, while, in Gebel Maghara surface outcrops, it is represented by Bir Maghara Formation and the coal-bearing Safa Formation. The fossil content of the Upper Wadi El Natrun member in SH-4 Well assigned it to the Bajocian age, while Khatatba Formation is assigned to Bathonian age (SH-4 bio-stratigraphic report, Georesearch Company, 2015).

Accordingly, in SH-4 well the Aalenian Middle Wadi El Natrun member of $70 \mathrm{ft}$ thickness sandstone is directly overlain by the Bajocian shallow marine shale/ carbonate section of the Upper Wadi El Natrun member (equiv. to Bir Maghara Formation of Al Far, 1966).

The depositional regime was changed into the deltaic complex of the dominated organic rich shale, coal seams and sandstone inter-beds of Khatatba Formation.

Khatatba Formation depositional regime allowed it to be considered the main Jurassic hydrocarbon source rock in the subsurface of the Western Desert (Enap Sipetrol, 2007). Khatatba Formation includes two potential reservoirs in the subsurface that are separated by Kabrit carbonate/Shale Member (300 ft.) known as Upper and Lower Safa Members in addition to Zahra shale and carbonates at the top of the formation.

\section{Upper Carbonate Mega-Sequence}

During the Bathonian-Callovian transition time, a tectonic pulse took place (Cimmerian rifting tectonic phase) resulted in the change in the depositional regime of Khatatba shallow marine to the open marine Masajid carbonate. In SH-4 Well, Zahra shale-carbonate Member (300') at top of Khatatba Formation remarks this transition in the depositional regime. The fossil content of the Masajid Formation in SH-4 


\section{Geological framework of Jurassic sequences, East Tiba sub-basin}

Well assigned it to Callovian-Oxfordian age. It is mainly composed of $1000 \mathrm{ft}$. thick marine carbonate sequence, showing a great variation in thickness due to the regional unconformity at its top.

\section{SUMMARY AND CONCLUSIONS}

1. The encouraging gas discoveries in East Tiba Sub-Basin gave the initiatives for studying of the Triassic to Middle Jurassic sequences in the context of the tectono-stratigraphic approach.

2. The biostratigraphic data analysis defined the Late Triassic-Early Jurassic rifting event that could be differentiated between the Lower and Upper Ras Qattara members.

3. The lithostratigraphic and biostratigraphic correlation revealed the presence of Jurassic depocentre at Gebel Rissu area.

4. The marine Jurassic rocks of Gebel Rissu area change laterally westwards into anon-marine sandstones reflecting the presence of Paleo-high in the western part of the study area during the Jurassic time.

5. The main subsurface Jurassic rocks are regionally correlated with those exposed at Gebel El Maghara outcrop in North Sinai.

6. The Middle Jurassic Upper Safa Member (Middle-Upper Bathonian) is considered the main reservoir unit in the Khatatba Formation, while the Lower Safa Member (Lower Bathonian) is considered as the second reservoir target.

7. The Middle Wadi El Natrun member (Shusha Formation equivalent) of the Middle Jurassic Aalenian age is mainly sandstone and proved to be a gas prolific reservoir in the study area.

8. Ras Qattara Formation (Triassic-Lower Jurassic) can be subdivided into two members. Upper and Lower, separated from each other by an intra-formational unconformity.

\section{ACKNOWLEDGEMENTS}

The authors would like to thank PetroShahd Company and their partners, Egyptian General Petroleum Corporation (EGPC), Enap Sipetrol and Kuwait Energy Companies for permission to use and publish this material.

\section{REFERENCES}

Alfar, D. (1966): Geology and coal deposits of Gebel El Maghara (Northern Sinai). UAR Geol. Surv. Paper 37, 59 pp.

Ayyad, M. H. and Darwish, M. (1996): Syrian arc structures: a unifying model of inverted basins and hydrocarbon occurrences in North Egypt. $13^{\text {th }}$ E.G.P.C. Petrol Expl. and Produc. Conf., 40-60.

Badalini, G., Redfern, J. and Carr, I. D. (2002): a synthesis of current understanding of the structural evolution of North Africa. J. Petrol. Geol., 25(3), 249-258.

DARWISH, M., EL AZABY, M. H., EID, A. A. and MOUSSA, S., (2000): hydrocarbon habitat of source Mesozoic sedimentary basins, onshore west Nile Delta, Egypt (an evaluation model). $5^{\text {th }}$ Inter. Conf. on the Geology of the Arab World, Cairo Univ., 735-760.

DARWISH, M. and TEWFIK, N., (2008): the sequence stratigraphy and facies of the Jurassic-Lower Cretaceous rift system in NE Africa. Geology of East Libya, 1, 345-368.

GUIRAUD, R., (1998): Mesozoic rifting and basin inversion along the northern African Tethyan margin: an overview in: Petroleum Geology of North Africa. Geol. Soc. London, Spec. Publ., 132, 217-229.

GUIRAUD, R., (1999): Paleozoic geodynamic evolution of the northeastern African Epicratonic basins: an outline. In: Feist, R., Talent, J.A. \& Daurer, A. (eds) North Gondwana: Mid-Paleozoic Terranes, Stratigraphy and Biota. Abhandlungen der Geologischen Bundesanstalt, Wien, 54, 15-26.

GUIRAUD, R. and BOSWORTH, (1999): Phanerozoic geodynamic evolution of northeastern Africa and the northwestern Arabian platform. Tectonophysics, 315, 73-108.

KEELEY, M. L., and WALLIS, R.J., in press (1991): the Jurassic system in Northern Egypt: depositional and tectonic regimes. J. Petrol. Geol. 14(1), PP. 49-64.

KEELEY, M.L., DUNGWORTH, G., FLOYD, C.S., FORBES, G.A.F., KING, C., McGARVA, R.M. and SHAW. D., (1990): the Jurassic system in northern Egypt: regional stratigraphy and implication for hydrocarbon prospectivity. J. Petrol. Geol., 13(4), 397-420.

MESHREF, (1990): tectonic framework of Egypt. In The Geology of Egypt (ed. R. Said). Balkema, Rotterdam, 734 p. 
Fahmy, et al.

MOUSTAFA, A. R., (2008): Mesozoic-Cenozoic basin evolution in the North Western Desert of Egypt. Sedimentary basins of Libya, $3^{\text {rd }}$ Symposium: Geology of East Libya, 2008, Vol. 3, PP. 29-46.

MOUSTAFA, A. R., (2013): fold-related faults in the Syrian arc belt of Northern Egypt. Marine and Petroleum Geology 48 (2013), 441-454.

NAGATY, (1986): possible Mesozoic rifts in Upper Egypt: an Analogy with the Geology of YemenSomalia Rift Basins. VIII EGPC Expl. Conference. Cairo, PP. 1-18.

NORTON, (1967): rock stratigraphic nomenclature of the Western Desert. Internal report, Pan- American U.A.R. Oil Company (now AMOCO), Cairo, 18pp.

PALEOSERVICES, (1988): the hydrocarbon potential of the Jurassic system in Northern Egypt north of $\left.30^{\circ} \mathrm{N}\right)$. Commercial non-exclusive report, Watford, UK and EGPC, Cairo.

PGS, (2001): regional sedimentary basins, north Western Desert, Egypt.

SAID, R., (1962): the Geology of Egypt. Elsevier, Amsterdam, 377 p.

Schandelmeier and Reynolds, (1997): Palaeogeographic-Palaeotectonic Atlas of North Eastern Africa, Arabia and Adjacent Areas. Balkema, Rotterdam, 160 p.

Wescott, W. A., Atta, M., Blanchard, D., Cole, R. M., Georgeson, S. T., Miller, D. A., O’hayer, W. W., Wilson, A. D., Dolson, J. C., and Sehim, A., (2011): Jurassic rift architecture in the northeastern Western Desert, Egypt, Search and Discovery Article \#10379.

\section{Un-published Internal Reports:}

AMOCO, (1968): Kattaniya-1 final well report.

ENAP SIPETROL, (2004): Shahd-1 final well report.

ENAP SIPETROL, (2007): SH SE-7 final well report.

ENAP SIPETROL, (2016): SH-4 final well report.

FAHMY, M., and AZZA SAMY, (2016): location map of wells that penetrating Jurassic sequences, East Tiba Sub-Basin, northern Western Desert, Egypt. Internal report no. 16, Enap Sipetrol.

GEORESEARCH, (2015): SH-4 well bio-stratigraphic report.

GOOGLE MAP, (2016): study area location map.

ISKANDER, (2016): Wadi El Natrun Formation structural depth map. 
Geological framework of Jurassic sequences, East Tiba sub-basin

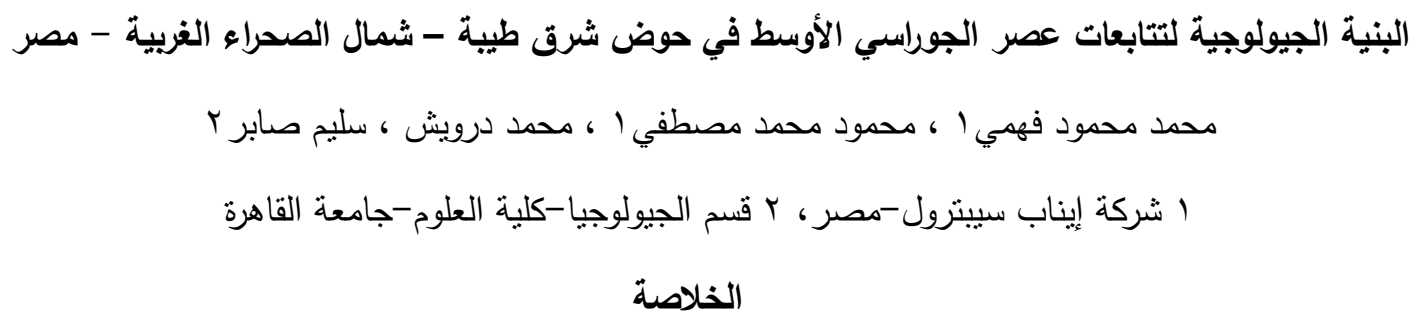

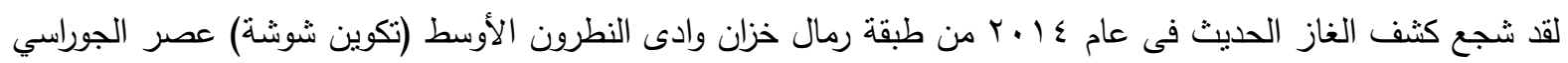
الأوسط في حوض شرق طيبة الفرعي في منطقة امتباز شهد ، شمال الصحراء الغربية، مصر إلي دراسة وتقيبم الخزانات

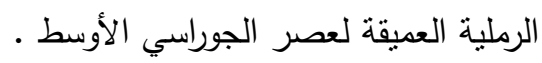

كثفت الدراسة أن الصخور الرسوبية التابعة لهذا العصر الجوراسي تعرضت لمراحل تكوينية متعددة أدت إلي ترسيب تكوين

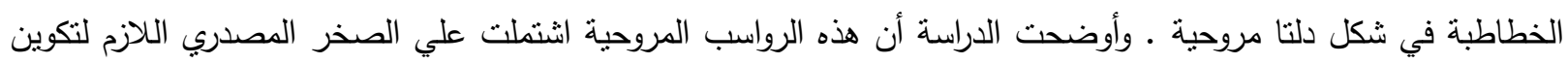

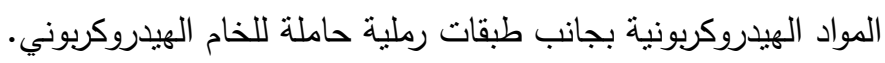

ونظرا لهذه الحركات الأرضية التي أثرت في مستوي سطح البحر في الحوض الترسيبي وكذلك تغيير الظروف المناخية مما

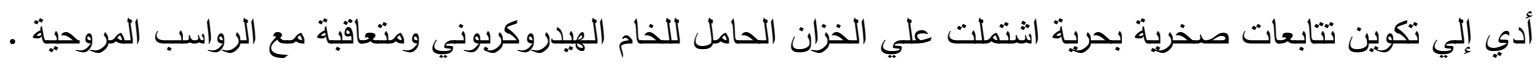
واشتملت الدراسة علي مقارنة هذه التتابعات بمثناتها المكثوفة علي السطح بمنطقة جبل المغارة بشمال سيناء والثابعة

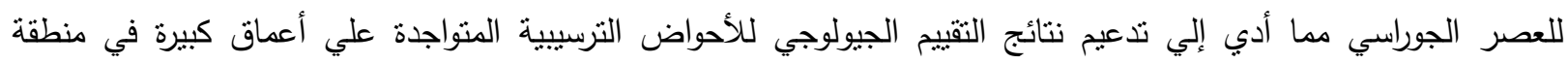

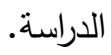

ولقد أوضحت الدراسات السيزمية ثلاثثية الأبعاد شكل وحدود الأحواض الترسيبية والصدوع المصاحبة لها مما ساعد علي تقسيم رواسب هذه الأحواض إلي تتابعات صخرية ذات أعمار جيولوجية محددة في الحوض الجوراسي الترسيبي بمنطقة الدراسة. 